\title{
Dark stains on rock surfaces in Driny Cave (Little Carpathian Mountains, Slovakia)
}

\author{
Rafał Ogórek ${ }^{1}$ Mariusz Dyląg ${ }^{1}$ Bartosz Kozak ${ }^{2}$
}

Received: 24 March 2016 / Accepted: 6 June 2016 / Published online: 17 June 2016

(C) The Author(s) 2016. This article is published with open access at Springerlink.com

\begin{abstract}
Mycobiota are important in underground ecology. In 2014, we discovered dark stains on clayey sediments on the walls of Driny Cave, Slovakia. Our description is based on the morphology of the fungus and the phylogenetic relationships of the internal transcribed spacer (ITS) region. In addition, data on its capacity for the production of extracellular enzymes, growth, and survival in vitro at different temperatures are reported. Our analyses revealed that this dark stains on the wall was produced by Penicillium glandicola. The fungus was able to synthesize amylases, proteases and cellulases, but not pectinases and keratinases. The vegetative structures of mycelium of this fungus are viable in vitro after storage at cool temperatures (from -72 to $5{ }^{\circ} \mathrm{C}$ ), and show active growth at temperatures from 5 to $25^{\circ} \mathrm{C}$, but without spore germination, and without active growth at 30 and $37{ }^{\circ} \mathrm{C}$. Penicillium glandicola is a psychrotolerant species and belong to var. glandicola.
\end{abstract}

Communicated by L. Huang.

Rafał Ogórek

rafal-ogorek@wp.pl

Mariusz Dyląg

mariusz.dylag@uwr.edu.pl

Bartosz Kozak

bartosz.kozak@up.wroc.pl

1 Department of Genetics, Institute of Genetics and Microbiology, University of Wroclaw, Przybyszewskiego Street 63/77, 51-148 Wroclaw, Poland

2 Department of Genetics, Plant Breeding and Seed Production, Wrocław University of Environmental and Life Sciences, pl. Grunwaldzki 24a, 50-363 Wroclaw, Poland
Keywords Driny Cave · Dark stains · Enzymatic activity · Penicillium glandicola

\section{Introduction}

Microorganisms play a crucial role in maintaining the delicate ecological balance of the earth, and they are capable of colonizing almost every niche (Sustr et al. 2005; Bastian et al. 2010). Therefore, the mycobiota are very important for underground ecology, because the fungi present are decomposers or parasites and probably constitute the major food source for various organisms (Sustr et al. 2005; Walochnik and Mulec 2009; Bastian et al. 2010). Generally, evidence for microbial activity in a cave includes spots on the cave surfaces, unusual coloration of speleothems, precipitates, corrosion residues, structural changes, and the presence of biofilms (Barton 2006). Additionally, microscopic fungi and bacteria may be isolated from various substrates and places in caves and other underground sites such as air, sediments, vermiculations, bat guano, decaying organic material, rock surfaces, bioaerosols, etc. (Nováková 2009; Ogórek et al. 2016a, b; Walochnik and Mulec 2009; Vanderwolf et al. 2013; Borda et al. 2014; Popović et al. 2015).

On the other hand, ecosystems, such as caves or underground facilities created by man are one of the most inhospitable habitats for microbial life (especially for fungi) due to nearly complete darkness, relatively constant low temperatures of air and water, and a poor supply of easily degradable organic matter, with the exception of beneficial relative humidity of air (Vanderwolf et al. 2013; Pusz et al. 2014, 2015; Ogórek et al. 2014a). Therefore, the majority of fungi cannot usually actively grow in the environment of underground facilities, but they are present regularly or 
rarely as spores or conidia, carried by water, air currents, bats, arthropods and humans (Kubátová and Dvořák 2005; Jurado et al. 2010; Vanderwolf et al. 2013; Griffin et al. 2014). The most fungi are obtained from the twilight zone or places with access to the external environment, e.g., ventilation shafts (Ogórek et al. 2013, 2014a, b, c; Ogórek and Lejman 2015).

Currently, the literature reports many cases of the visible presence of bacteria in caves, e.g., yellow subaerial biofilms on a stalactite and rock surfaces (Jurado et al. 2010, Mulec et al. 2015) or yellow and white microbial mats on rock surfaces (Northup et al. 2011), and many others (Barton and Northup 2007; Ivanova et al. 2013; Marshall Hathaway et al. 2014). However, similar reports with regard to the active growth of filamentous fungi on rock surfaces in caves are very few and mostly relate to the Lascaux Cave in France (Martin-Sanchez et al. 2011, 2012a, b; Saiz-Jimenez et al. 2012).

Visible growth of fungi in caves more often was found on wood, carcasses, bat droppings (e.g. Trichoderma polysporum), and entomopathogenic fungi have been found on dead or hibernating insects (Kubátová and Dvořák 2005; Nováková 2005, 2009). Additionally, it should be noted that the active growth of fungi in buildings are frequently reported, and they are quite common, especially under conditions of poor ventilation and high moisture, but on walls in caves they are exceptional (Garg et al. 1995; Berner et al. 1997; Gorbushina et al. 2004).

The aim of this study was to perform molecular and morphological identification of fungi isolated from the dark stains on clayey sediments on the wall in Driny Cave. Additionally, the isolated fungus was also assessed for the production of extracellular enzymes, growth rates and survival at different temperatures.

\section{Materials and methods}

\section{Study area}

Driny Cave is located in the Smolenice Karst in the Lesser Carpathian Mountains, south-west from Smolenice, in the Trnava district and near the recreation resort Jahodník (Slovakia). Geographic coordinates of the cave are $48^{\circ} 50^{\prime} 04^{\prime \prime} \mathrm{N}, 17^{\circ} 40^{\prime} 20^{\prime \prime} \mathrm{E}$. Its entrance is situated on the western slope of Driny Hill at $399 \mathrm{~m}$ a.s.l. and its length is $680 \mathrm{~m}$. The cave was discovered in 1929 by Jan Banic and Jan Vajszabel, and it was opened to the public in 1935 with provisional electric lighting $175 \mathrm{~m}$ in length. Now, the length of the tourist path is $410 \mathrm{~m}$ (Lehotská et al. 2011; Briestenskỳ et al. 2011). The air temperature in the cave is between 7.1 and $7.8{ }^{\circ} \mathrm{C}$, and relative humidity is between 92 and 97 \% (Bella et al. 2001). In 2014 alone Driny Cave was visited by ca. 31859 people (Nudziková 2014).

\section{Sample collection}

The samples were taken on 25 July 2014. The dark stains was found only in a single location on clayey sediments on the wall (about $1.0 \mathrm{~m}$ above the level of the floor) in the cave (Passage of Hopes)-Figs. 1 and 2. The samples were collected using sterile swabs wetted in physiological saline $(0.85 \% \mathrm{NaCl})$, in transport tubes. Material was sampled with nine swabs.

\section{Isolation of fungi from swabs (streaking, rinse procedure and putting swabs on medium)}

Streaking procedure - the surface of solidified Potato Dextrose Agar medium (PDA, Biocorp) was streaked in a zigzag pattern with a swab (in three replicates). Rinse procedure-sample was shaken for $20 \mathrm{~min}$ in a $50-\mathrm{ml}$ Erlenmeyer flask containing $10 \mathrm{ml}$ of sterile distilled water. After shaking, the sample was placed in a Petri dish, on solidified PDA medium (in three replicates), using the serial dilution technique. Putting swabs on medium-sample was placed on Petri dishes with solidified PDA medium (in three replicates).

\section{Identification of fungi}

After incubation of the samples from swabs $\left(8\right.$ and $25{ }^{\circ} \mathrm{C}$, 7-28 days), emerging colonies of fungi on the plates were subcultured on PDA media (isolates were purified by the single spore method) for morphological and molecular identification.

The morphological identification of the collected fungi was performed using macro- and microscopic observations of the colonies that had grown on the culture media: PDA, Malt Extract Agar (MEA, Biocorp), Czapek-Dox Agar (1.2\% agar, Biocorp), CYA (Czapek Yeast Autolysate agar: $30.0 \mathrm{~g} \mathrm{~L}^{-1}$ sucrose, $15 \mathrm{~g} \mathrm{~L}^{-1}$ agar, $5.0 \mathrm{~g} \mathrm{~L}^{-1}$ yeast extract, $3.0 \mathrm{~g} \mathrm{~L}^{-1} \mathrm{NaNO}_{3}, 1.0 \mathrm{~g} \mathrm{~L}^{-1} \mathrm{~K}_{2} \mathrm{HPO}_{4}, 0.5 \mathrm{~g} \mathrm{~L}^{-1}$ $\mathrm{KCl}, 0.5 \mathrm{~g} \mathrm{~L}^{-1} \mathrm{MgSO}_{4} \cdot 7 \mathrm{H}_{2} \mathrm{O}, 0.01 \mathrm{~g} \mathrm{~L}^{-1} \mathrm{FeSO}_{4} \cdot 7 \mathrm{H}_{2} \mathrm{O}$ ), and YPG (yeast extract peptone glucose: $10.0 \mathrm{~g} \mathrm{~L}^{-1}$ yeast extract, $20.0 \mathrm{~g} \mathrm{~L}^{-1}$ peptone, $20.0 \mathrm{~g} \mathrm{~L}^{-1}$ glucose, $15.0 \mathrm{~g} \mathrm{~L}^{-1}$ agar)-Fig. 3. Plates were incubated in plastic boxes for 7 day in the dark at $25^{\circ} \mathrm{C}$ (Fig. 4). The fungi were identified using diagnostic keys (Seifert and Samson 1986; Pitt and Cruickshank 1990; Visagie et al. 2014). Subsequently, the fungus was genetically analyzed to confirm the affiliation of the species. 


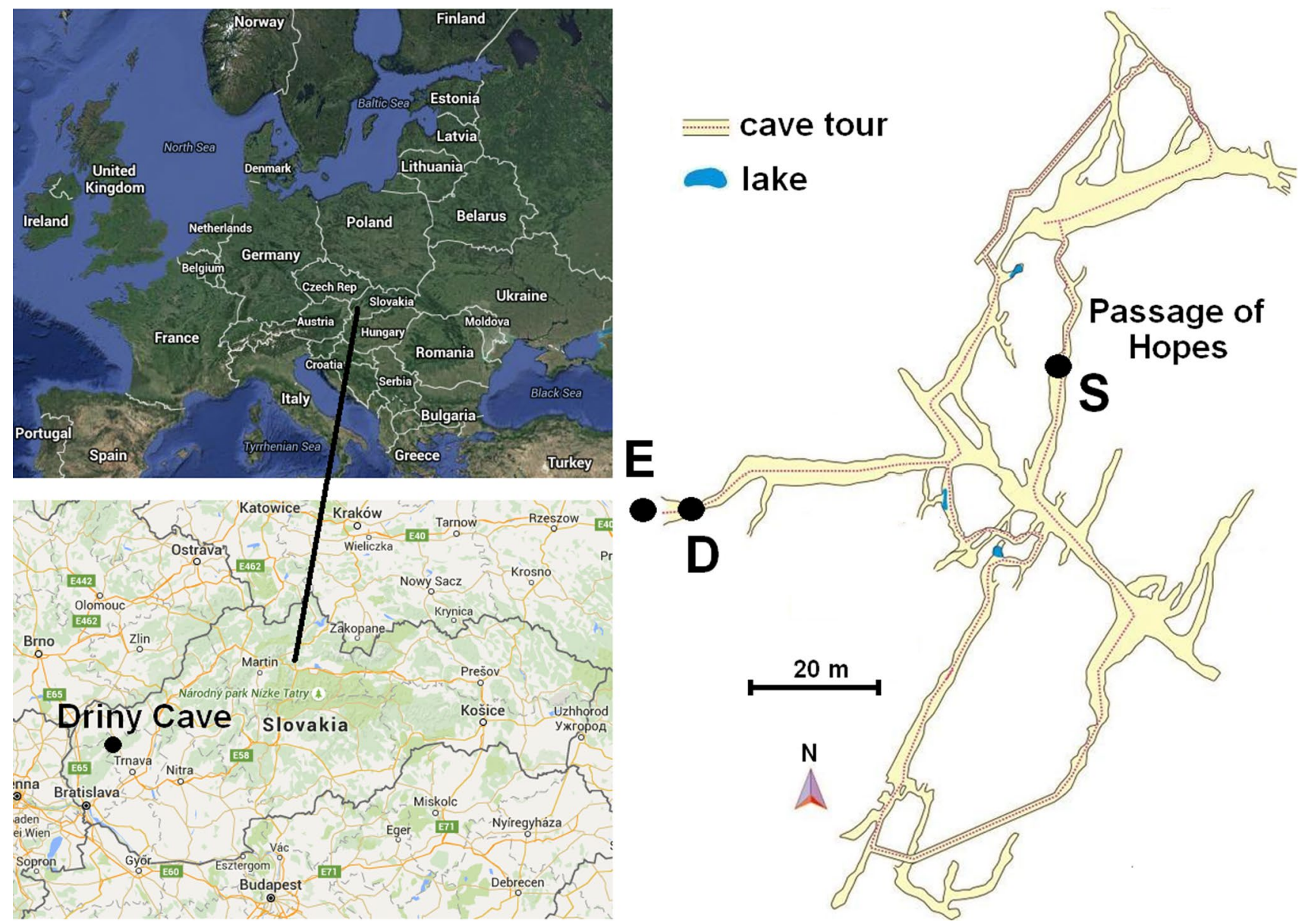

Fig. 1 Geographic location of Driny Cave in Slovakia and map of the tourist route: $E$ entrance and exit of the cave, $D$ airlock door, $S$ sampling location

DNA was extracted from 10-day-old strains on PDA medium, according to the CTAB method (Doyle and Doyle 1987) with minor modifications (Ogórek et al. 2012). Amplification of DNA was performed in a $50 \mu$ l reaction mixture using the $2 \times \mathrm{PCR}$ mixture containing a Taq polymerase

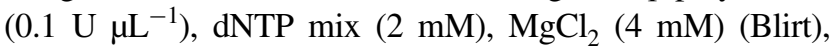
$0.25 \mu \mathrm{M}$ of each primer, ITS1: TCCGTAGGTGAACCTGCGG, ITS4: TCCTCCGCTTATTGATATGC, and ITS1 and ITS4 primers, ITS1: TCCGTAGGTGAACCTGCGG, ITS4: TCCTCCGCTTATTGATATGC (White et al. 1990) and $45 \mathrm{ng}$ of genomic DNA. Amplification was performed in the Biometra thermal cycler for 35 cycles. After initial denaturation for $5 \mathrm{~min}$ at $94{ }^{\circ} \mathrm{C}$, each cycle comprised $30 \mathrm{~s}$ denaturation at $94{ }^{\circ} \mathrm{C}, 30 \mathrm{~s}$ annealing at $55^{\circ} \mathrm{C}, 45 \mathrm{~s}$ extension at $72{ }^{\circ} \mathrm{C}$ with a final extension for $7 \mathrm{~min}$ at $72{ }^{\circ} \mathrm{C}$ at the end of 35 cycles. The amplification product was separated on agarose gel $(1.5 \%)$, visualized by UV light, purified from gel and sequenced by the Sequencing Service at Macrogen (http:// dna.macrogen.com/eng/). The PCR product sequences were compared with the published ITS sequence database from the National Center for Biotechnology Information (NCBI, Bethesda, MD, USA) using the BLAST algorithm (http:// www.ncbi.nlm.nih.gov/).

\section{Enzymatic activity}

The fungal strain was screened for the production of extracellular amylases, proteases, cellulases and pectinases by plate assay according to Ogórek (2016).

Additionally, it was assessed for the production of keratinophilic enzymes using the in vitro hair perforation test. Cut human blonde hairs (pieces ca. $2 \mathrm{~cm}$, free from dust, oil and dandruff) from a 2.5-year-old child were thoroughly washed and rinsed in distilled water. After drying at room temperature, ca. 30 hair segments were placed into a glass Petri dish and sterilized in an autoclave ( $1 \mathrm{~atm}$. for $20 \mathrm{~min}$ ). After the Petri dishes had cooled, $25 \mathrm{ml}$ of sterile distilled water and $100 \mu \mathrm{L}$ of a 

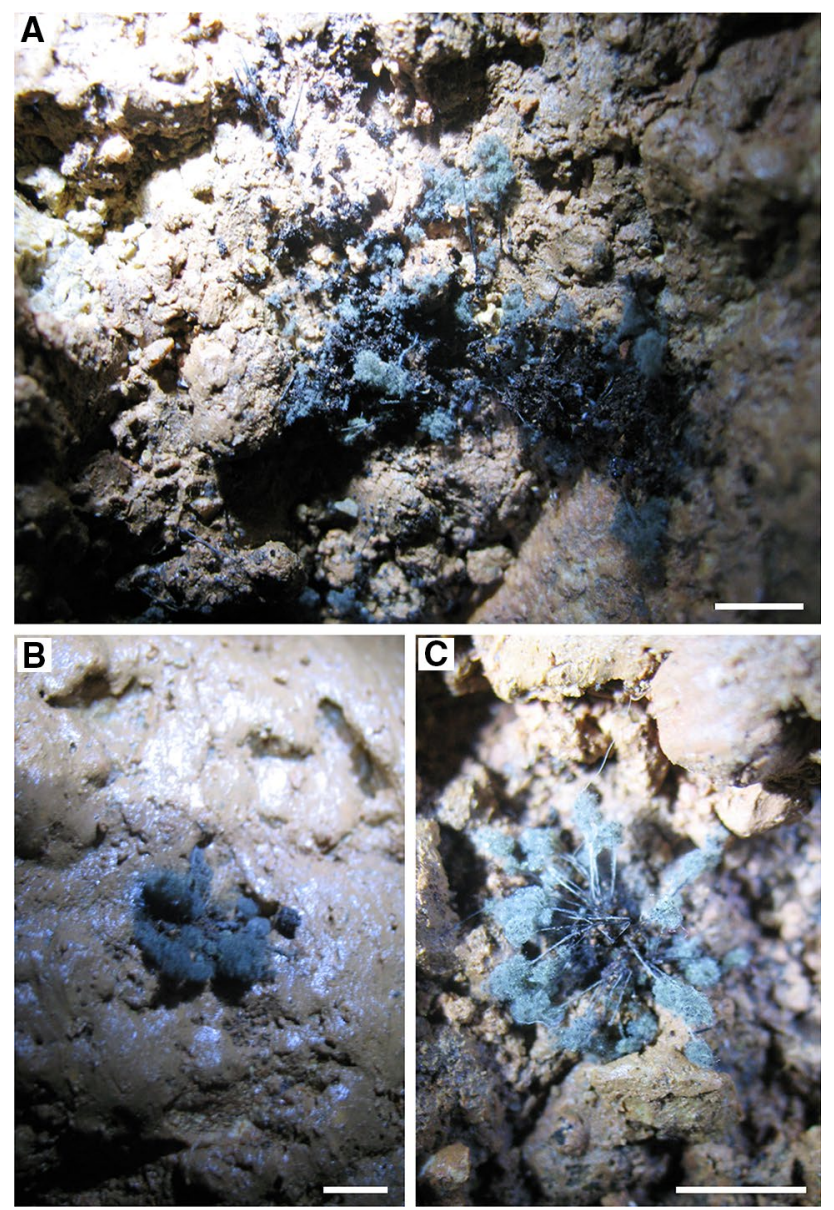

Fig. 2 Dark stains on clayey sediments on the walls in Driny Cavecoremia of Penicillium glandicola. Scale bars A $20 \mathrm{~mm} ; B, C 4 \mathrm{~mm}$

sterile $10 \%$ yeast extract solution were aseptically added to each plate and inoculated with the investigated culture (spore suspension, prepared from 10-day-old colonies). The positive control was also prepared in a similar way, but with Trichophyton mentagrophytes (clinical strain from Dyląg M. collection, Department of Genetics, Institute of Genetics and Microbiology, University of Wroclaw) and the negative control without fungi. All variants of experiments were incubated at $25{ }^{\circ} \mathrm{C}$ for 4 weeks. Single hairs or their segments were removed from the Petri dishes, and cleared in sterile distilled water. Then, an individual hair was placed on the microscopic slide and stained with lactophenol for microscopic observations. This allowed us to detect whether any hair perforation had taken place compared to the positive control with $T$. mentagrophytes.

\section{Survival at different temperatures}

Fourteen-day-old cultures on PDA slant and YPG slant were placed in different temperatures: $-72,-25,-10$, and $5{ }^{\circ} \mathrm{C}$. After $14,28,42$, and 56 days of storage at each temperature, the fungal inocula from three slants for each medium were placed mycelium down in the center of a Petri dish, on the PDA and YPG media, in three replicates. The survival of fungus (growth or no growth) was evaluated after 10 days incubation in the dark at $25{ }^{\circ} \mathrm{C}$.

\section{Growth at different temperatures}

Fungal spores were obtained from 14-day-old cultures, which were cultivated on PDA slant, and spores were suspended in a solution of $0.85 \% \mathrm{NaCl}$ with $0.025 \%$ Tween 80. The spore suspensions $\left(\mathrm{OD}_{600}=0.125, \sim 0.5 \mathrm{McFar}-\right.$ land) were placed $(5 \mu \mathrm{L})$ in the center of a Petri dish, on the PDA and YPG media (three replicates for each medium). Then, they were placed at different temperatures: $5,10,15$, $20,25,30$, and $37^{\circ} \mathrm{C}$. After $2,4,6,8$, and 10 days of inoculation in the dark, the colony growth was measured using an electronic digital caliper.

\section{Results}

We found active growth of fungi coating the surface of the clayey sediments on the wall in Driny Cave-Figs. 1 and 2. The swabs contained only one fungal species: Penicillium glandicola (Oudem.) Seifert \& Samson (Figs. 2, 3, 4, 5; Table 1).

The identification with a diagnostic key was confirmed by BLAST analysis of ITS1, 5.8S and ITS2 regions amplified in PCR (Table 1). The appearance of the colony of this species was determined by growth on different culture media, especially the color of aerial mycelium and rate of growth. It usually secreted a yellow to brown soluble pigment into the media. Additionally, it was distinguished by a granular texture from fasciculate to coremiform (especially on CYA and YPG media), usually with small coremia apparent at the margins. On CYA and YPG media, the reverse side of the colony showed furrows radially and was usually deep brown-Fig. 3. This species formed rough stipes with fasciculate texture, penicilli terverticillate to quaterverticillate, metulae sometimes apically inflated, phialides very short and subglobose to ellipsoidal, and conidia yellow-green in the mass with smooth walls $(2.95 \times 3.90 \mu \mathrm{m})$-Figs. 4 and 5.

The studied fungus showed differences in the ability to secrete extracellular enzymes. No pectinolytic and keratinophilic activity was detected. The most intensively synthesized enzymes were amylases, for which average enzymatic units (EU) in $1 \mathrm{~mL}$ of medium numbered $3.54 \times 10^{-3} \mathrm{EU}$ per $1 \mathrm{~mL}$. On the other hand, the least intensively synthesized enzymes were cellulases- $3.10 \times 10^{-5}$ EU per $1 \mathrm{~mL}$ of medium (Figs. 6, 7). 
Fig. 3 Penicillium glandicola, 10-day-old culture at $25^{\circ} \mathrm{C}$, top and bottom view of a colony on media: a PDA; b MEA; $\mathbf{c}$ Czapek-Dox Agar; d CYA; YPG
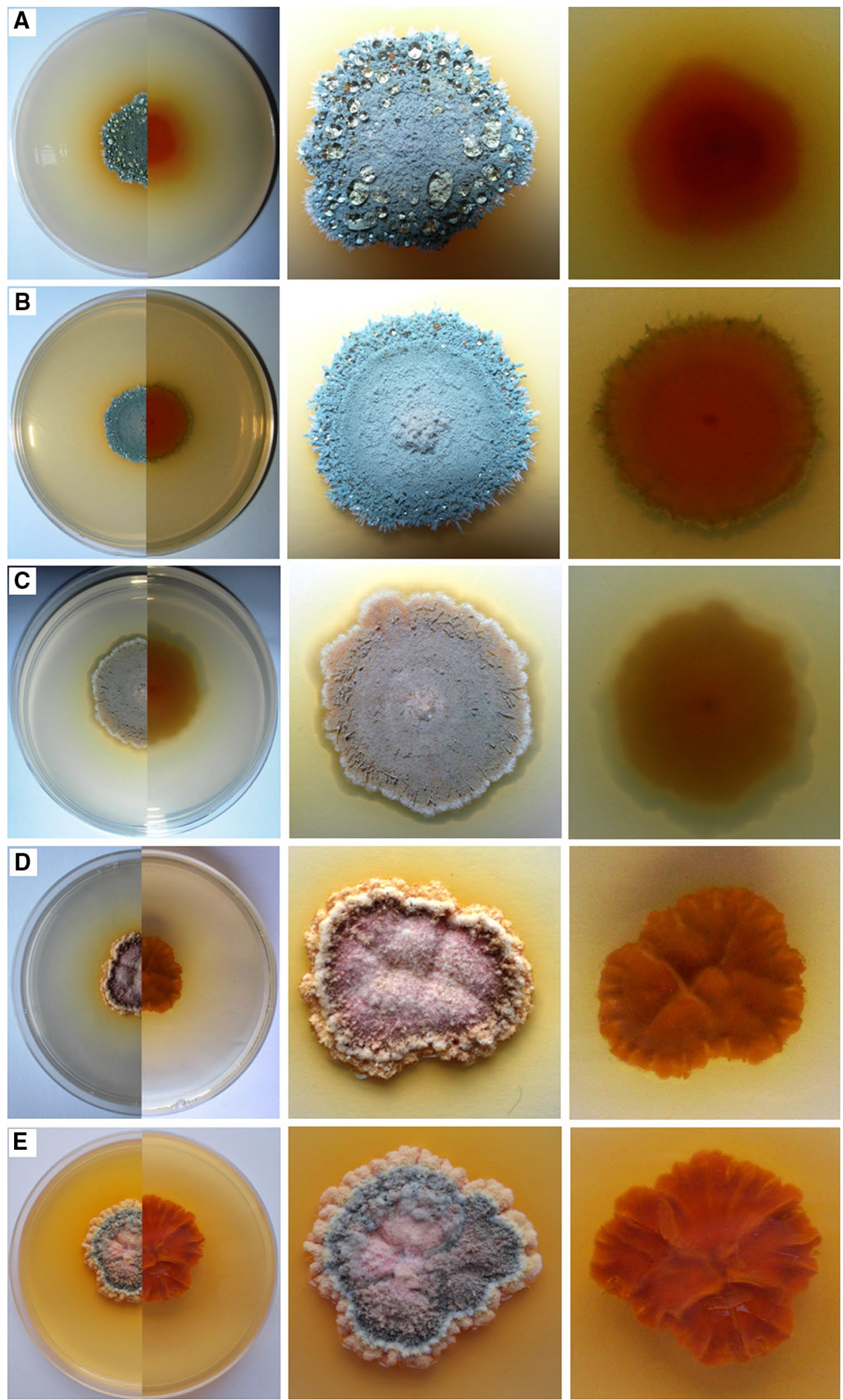

Fourteen-day-old cultures of tested fungus cultured on PDA and YPG slants were able to survive for 56 days (the maximum time tested) at different temperatures, from -72 to
$5{ }^{\circ} \mathrm{C}$ (Table 1). Additionally, the spores of this species were able to germinate and actively grow on PDA and YPG media at temperatures from 5 to $25^{\circ} \mathrm{C}$, but lacked this ability at 30 
Fig. 4 Penicillium glandicola on PDA, 28-day-old culture at $8{ }^{\circ} \mathrm{C}$ : $\mathbf{a}, \mathbf{b}$ top view of culture (after isolation of fungi from swabs-rinse procedure); c, d, e Petri dish cultures under the optical microscope, branched conidiophores. Scale bars $200 \mu \mathrm{m}$
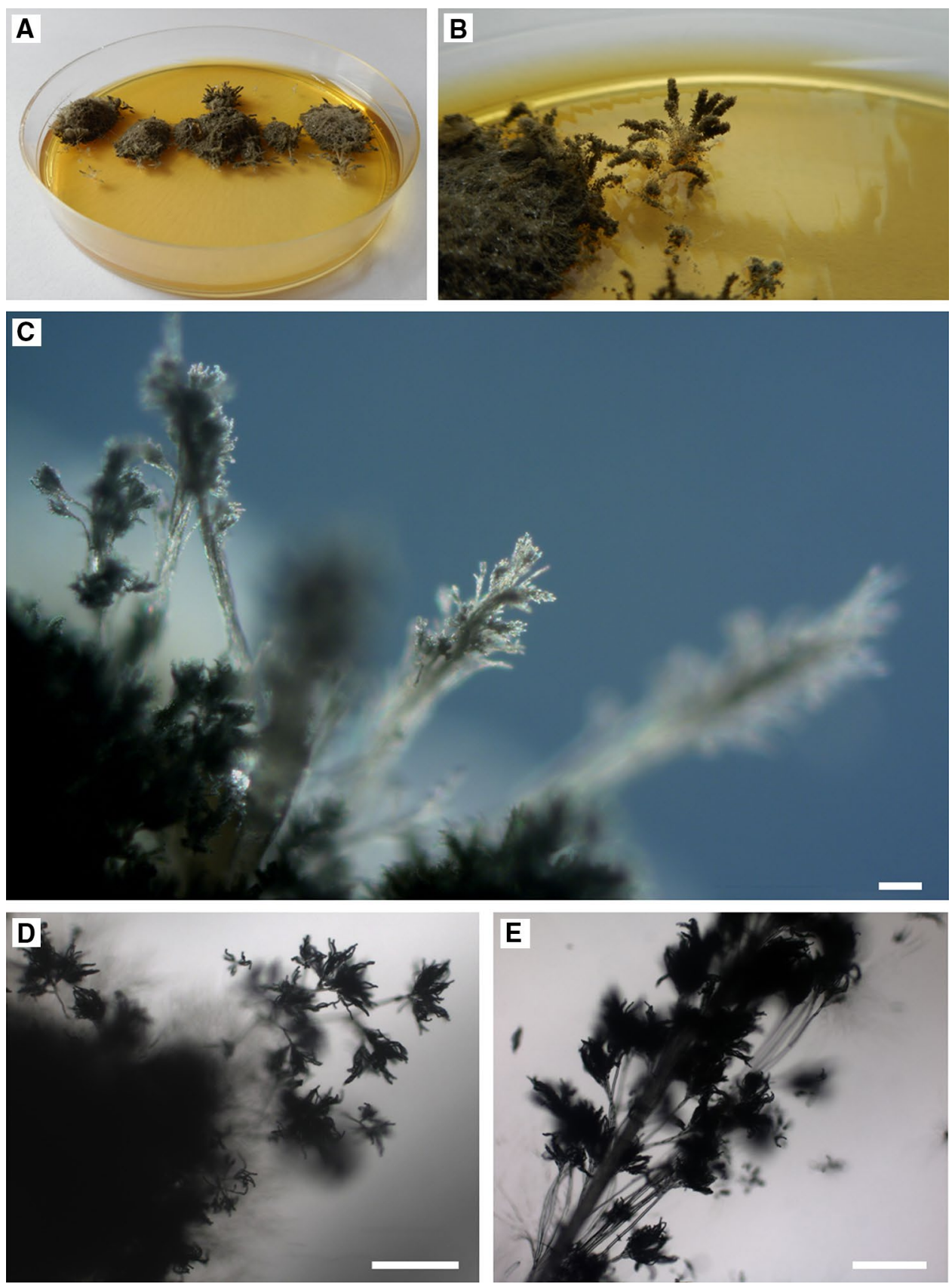

Table 1 BLAST analysis (the sequences were compared to Penicillium glandicola strain FRR 2036, Accession AY373916), and survival at different temperatures of fungus growing on the clayey sediments on the wall in Driny Cave

\begin{tabular}{lllll}
\hline Accession & Amplificaton product size (bp) & Query cover (\%) & Identities $(\%)$ & $E$ value \\
\hline KU687324 & 538.0 & 98.0 & 99.0 & $-25.0^{\circ} \mathrm{C}$ \\
\hline Incubation period (day) & $5.0^{\circ} \mathrm{C}$ & $-10.0^{\circ} \mathrm{C}$ & & $-72.0^{\circ} \mathrm{C}$ \\
\hline Survival at different temperatures & + & & + & + \\
14 & + & + & + & + \\
28 & + & + & + & + \\
52 & + & + & + & + \\
\hline
\end{tabular}

"+" fungal growth after a given period of storage on slant at a given temperature 
Fig. 5 Penicillium glandicola under the optical microscope, 7-day-old culture at $25^{\circ} \mathrm{C}$ : a branched conidiophores (PDA); b branch, ramus, metulae, phialides and conidia (MEA); c subglobose to ellipsoidal conidia (PDA); $\mathbf{d}$ stipes of rough branched conidiophores (PDA). Scale bars A $200 \mu \mathrm{m}$; $B, D 20 \mu \mathrm{m} ; C 10 \mu \mathrm{m}$
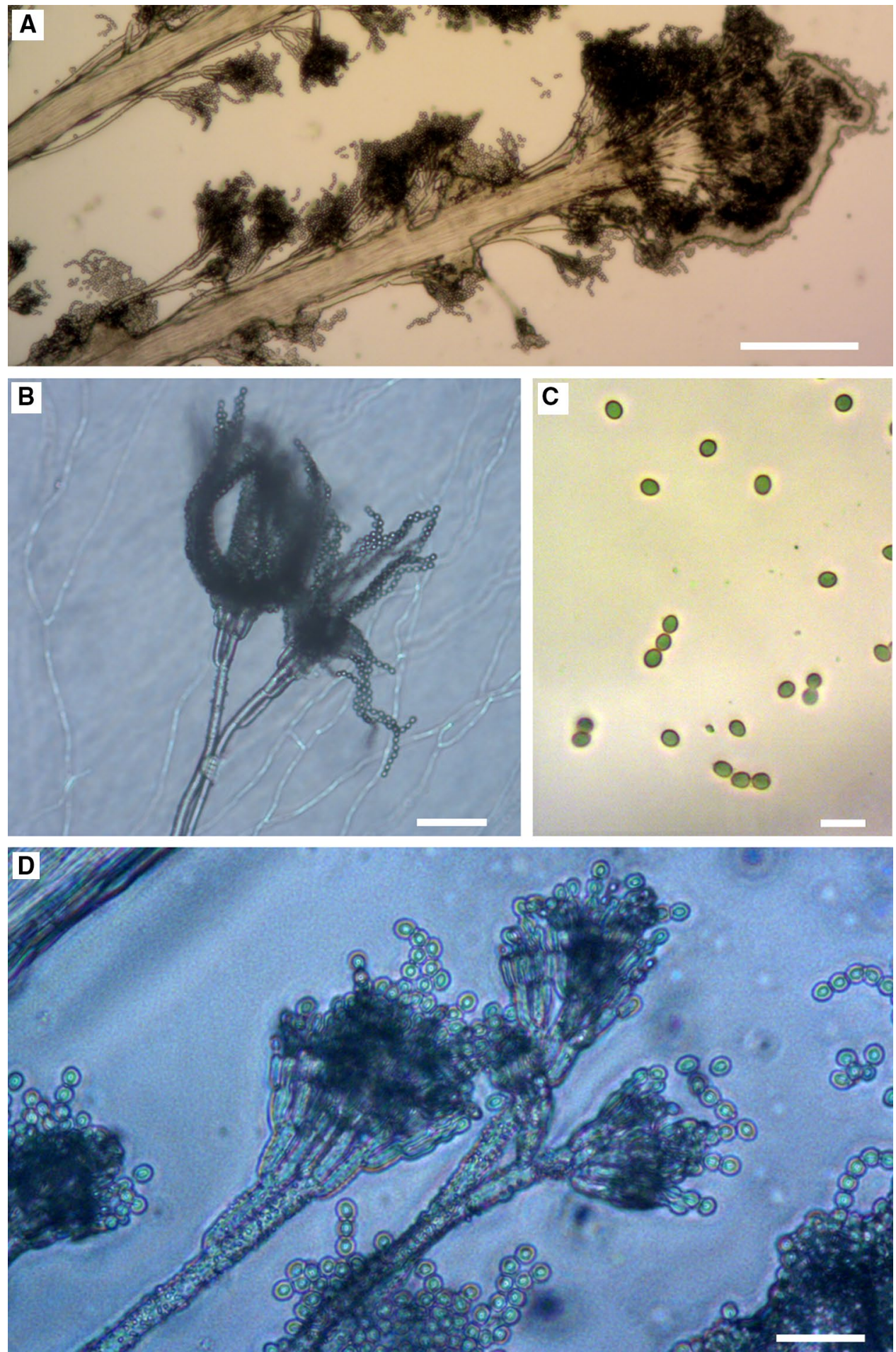

and $37^{\circ} \mathrm{C}$-Fig. 8. The optimal temperature for the growth of this isolate was $20{ }^{\circ} \mathrm{C}$ on both media. However, the colonies on YPG medium at all temperatures were larger (mean ca. $3.2 \mathrm{~mm}$ ) than on PDA medium. In the case of both media, the fungus showed visible growth of colonies after 2 days of incubation at $10,15,20$, and $25^{\circ} \mathrm{C}$, and after 4 days at $5{ }^{\circ} \mathrm{C}$.

\section{Discussion}

Fungi are eukaryotic microorganisms, comprising at least 1.5 million species, but only a few species are able to actively grow in underground niches. For example, white fungal stains consisting of Fusarium solani and black stains 
Fig. 6 Detection of extracellular enzyme activities in Penicillium glandicola by plate assay: a amylolytic activity; $\mathbf{b}$ proteolytic activity; c cellulolytic activity; $\mathbf{d}$ pectinolytic activity not detected. Average enzymatic units (EU) synthesized by fungi in $1 \mathrm{~mL}$ of medium $3.54 \times 10^{-3}$ EU for amylases, $1.37 \times 10^{-3} \mathrm{EU}$ for proteases and $3.10 \times 10^{-5} \mathrm{EU}$ for cellulases
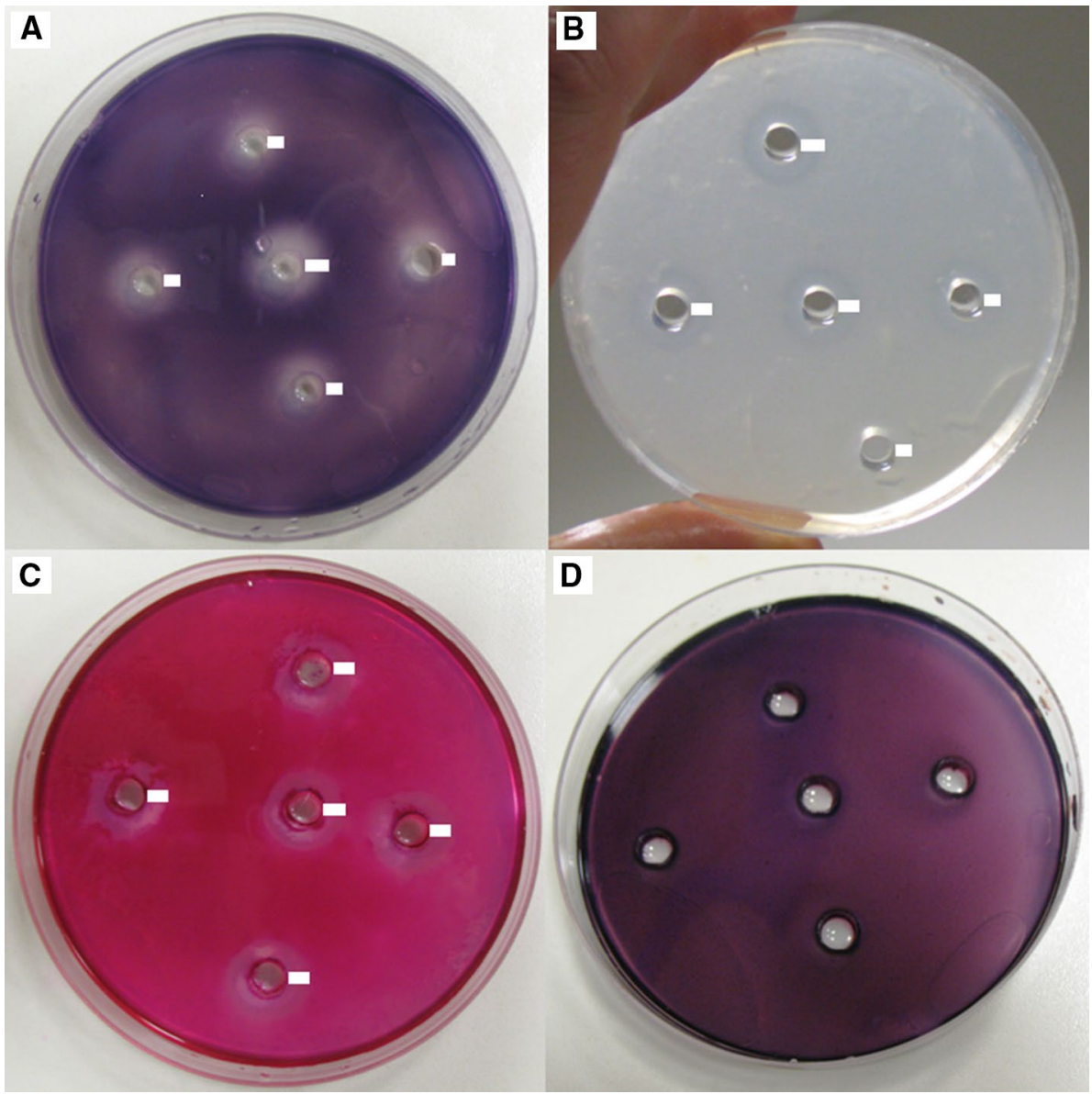

consisting of several filamentous fungi such as Ochroconis lascauxensis, O. anomala, Acremonium nepalense, Scolecobasidium tshawytschae, Herpotrichiellaceae sp. and Verticillium spp. and black yeasts such as Exophiala moniliae and E. castellani were found on the rock surface in the Lascaux Cave (Allemand and Bahn 2005; Bastian and Alabouvette 2009; Saiz-Jimenez et al. 2012; Martin-Sanchez et al. 2011, 2012a, b). We isolated only one fungal species (Penicillium glandicola) from the black stains on the surface of the clayey sediments on the wall in Driny Cave.

Penicillium glandicola (Oudem.) Seifert \& Samson (often called $P$. granulatum Bainier) belong to Subgenus Penicillium, Section Penicillium, Series Claviformia according to the recent classification of Frisvad and Samson (2004). Literature reports about multiple varieties of $P$. glandicola, e.g., var. confertum Frisvad, Filt. \& Wicklow, var. mononematosum Frisvad, Filt. \& Wicklow, var. glaucovenetum Frisvad and var. glandicola. Our species is likely P. glandicola var. glandicola, because it was not able to grow at 30 and $37{ }^{\circ} \mathrm{C}$, and it produces very rough stipes and branches. For example, P. glandicola var. confertum (syn. P. confertum (Frisvad, Filt. \& Wicklow) Frisvad) showed very good growth at $37^{\circ} \mathrm{C}$ (Frisvad and Samson 2004). On the other hand, P. glandicola var. mononematosum (as var. 'mononematosa', syn. P. mononematosum (Frisvad, Filt. $\&$ Wicklow) Frisvad), showed very good growth at $30{ }^{\circ} \mathrm{C}$, but no growth at $37^{\circ} \mathrm{C}$, and P. glandicola var. glaucovenetum (syn. P. concentricum Samson, Stolk and Hadlok) no growth at 30 and $37^{\circ} \mathrm{C}$ (Bridge 1985; Frisvad and Samson 2004). However, P. glandicola var. glandicola produce very rough stipes in contrast to var. mononematosum and var. glaucovenetum (Frisvad and Samson 2004).

This species may be isolated from a wide range of substrate types such as soil, foods, plants, air, bat guano, mammalian dung, earthworm casts, rock surfaces, etc. (Nováková 2009; Bezerra et al. 2012; Ogórek et al. 2016a, b). The literature also reported that the active growth of this species was found on marten excrement in Domica Cave (Slovakia), but it was identified only by morphological features and without detailed characterization (Nováková 2005). Therefore, our study is the first report regarding the active growth of P. glandicola in underground habitats supported with morphological and genetic identification and supplemented by detailed phenotypic and physiological characteristics of this strain.

Caves and other underground structures are likely a source of microbial extremophiles due to the extreme environments for life. Additionally, they provide ecological niches for highly specialized microorganisms (Schabereiter-Gurtner 
Fig. 7 The in vitro hair perforation test (lactophenol cotton blue preparation): a negative control without fungi; $\mathbf{b}$ positive control with Trichophyton mentagrophytes; c Penicillium glandicola was negative. Scale bars $100 \mu \mathrm{m}$

Fig. 8 Average colony diameters of Penicillium glandicola at different temperatures on PDA and YPG, without active growth at 30 and $37^{\circ} \mathrm{C}$
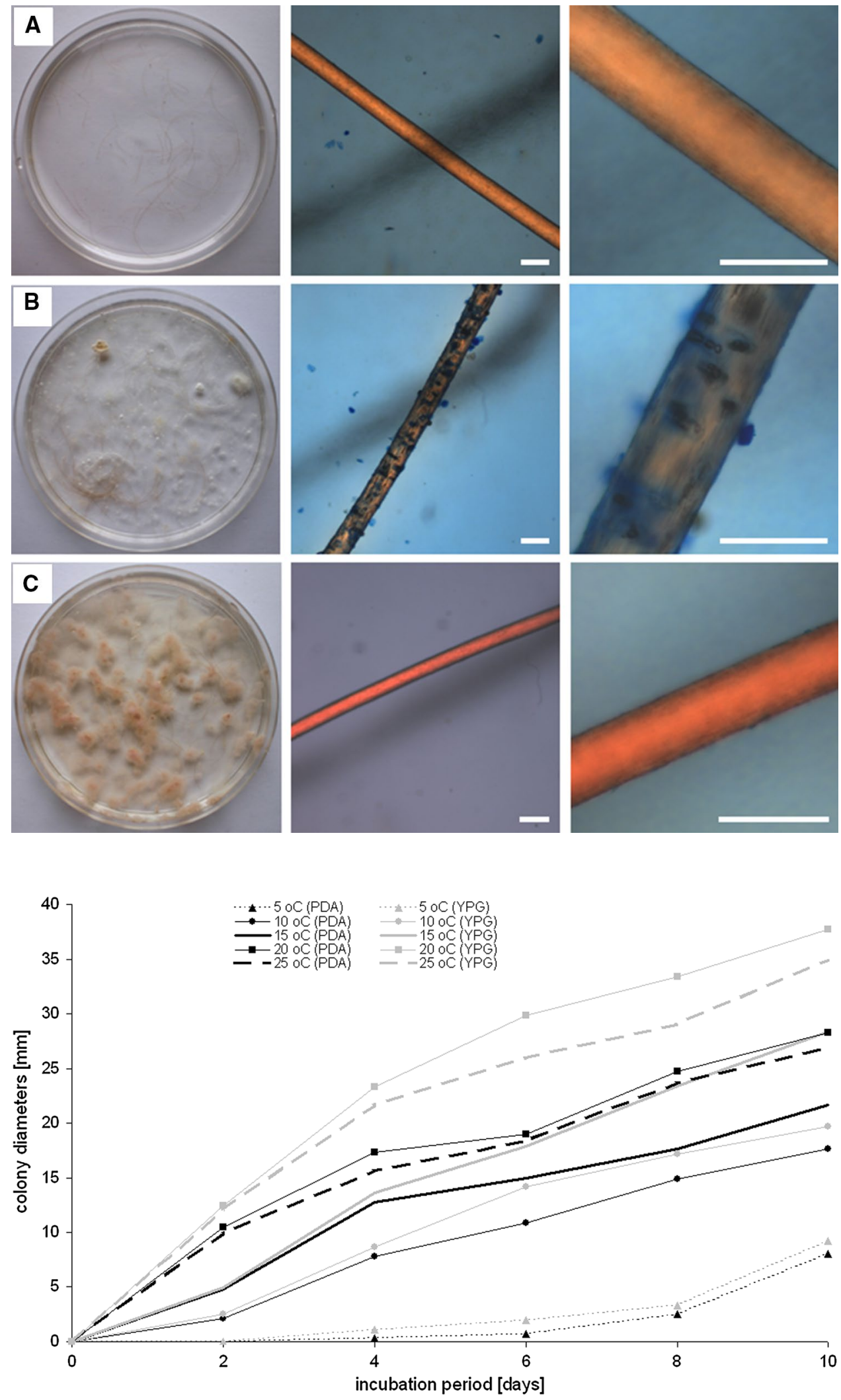
et al. 2004). Extremophiles are able to actively grow and survive in these environments, because they have developed mechanisms that allow them to cope with a variety of stressors (McKenzie et al. 2003). Penicillium glandicola isolated from the dark stains in Driny Cave was able to survive in vitro for 56 days at various low temperatures from -72 to $5{ }^{\circ} \mathrm{C}$, and it was also capable of active growth in vitro on different media from 5 to $25{ }^{\circ} \mathrm{C}$ (optimal $20{ }^{\circ} \mathrm{C}$ ). The obtained results correspond to reports of Frisvad and Samson (2004), in which P. glandicola is described as a psychrotolerant species that has growth optima in the range of mesophilic organisms, but is able to grow at low temperatures with much lower rates (Morita 1975; Wynn-Williams 1990).

Enzymes secreted by fungi play an important role in overcoming the natural resistance of the host (pathogenic process) as well as in providing soluble products that can be absorbed and used as food (Dobinson et al. 1996; Pekkarinen et al. 2000). Penicillium glandicola used in the study synthesized protease, cellulase and amylase, but not pectinase and keratinase. Therefore, this species is probably non-pathogenic to plants or humans and animals. Because pectinases cause modification of cell wall structure, increasing accessibility of cell wall components for degradation by other enzymes, cell lysis and plant tissue maceration (Panda et al. 2004). Thus, these enzymes are the first produced in infected tissue (Martínez et al. 1991). On the other hand, particularly important is the keratinophilic activity for the groups of fungi causing superficial fungal infections, e.g., dermatophytes that colonize skin, hair, and nails on the living host (Al-Fakih 2014). Because keratinous material is water insoluble and extremely resistant to degradation by common proteolytic enzymes such as trypsin, papain and pepsin, it has to be degraded by keratinases (Gupta and Ramnani 2006). Additionally, this species was not able to grow at $37^{\circ} \mathrm{C}$ - this is a virulence factor for fungi that invade deep tissue of humans and animals, and the transition to the parasitic form is essential for the pathogenicity of dimorphic fungi (Tomee and Kauffman 2000).

Ogórek et al. (2016c) carried out a mycological research in Driny Cave at the same time as our study. They detected the spores of $P$. glandicola in the air and the rock surfaces inside the cave, but not detected their in the external environment of it. Thus, this species was not transferred from the external environment into the cave. Literature reports that fungal species belonging to the Penicillium genus can affect rocks through biochemical degradation by the secretion of organic acids, cause oxidation of $\mathrm{Fe}(\mathrm{II})$ and $\mathrm{Mn}(\mathrm{II})$, adsorption of $\mathrm{Al}, \mathrm{Zn}, \mathrm{Cd}, \mathrm{U}$, $\mathrm{Th}, \mathrm{Pb}$, and $\mathrm{Sn}$, solubilization of rock phosphate and coal, reduction of $\mathrm{Fe}(\mathrm{III})$ as well as mineralization of materials such as halloysite and montmorillonite or todorokite
(Sterflinger 2000; Burford et al. 2003; Cwalina 2008). However, there are no reports of $P$. glandicola that can affect rocks. Probably, this species benefited from organic matter which was transferred from the external environment, e.g., with sediment or water. According to Ogórek et al. (2016a), P. granulatum (syn. P. glandicola) was the most frequently isolated fungal species from the guano of bats and the air around it. Thus, this species may be associated with bats and guano. Currently, we are unable to accurately explain the role of this species in the occupied ecological niche. Therefore, we are also going to perform further studies for in-depth characterization of P. glandicola from Driny Cave.

\section{Conclusions}

This is the first report regarding the active growth of $P$. glandicola in underground habitats with morphological and genetic identification and with the determination of phenotypic and physiological characteristics of this species. This species was able to synthesize amylases, proteases and cellulases, but not pectinases and keratinases. It was also capable of survival for 56 days at a broad range of very low temperatures (from -72 to $5^{\circ} \mathrm{C}$ ), active growth at temperatures from 5 to $25^{\circ} \mathrm{C}$, but without spore germination, and without active growth at 30 and $37^{\circ} \mathrm{C}$. Our research has shown that $P$. glandicola var. glandicola is a psychrotolerant species, which is capable of active growth under cold conditions as are typical for caves. The in vitro abilities of $P$. glandicola to produce extracellular enzymes and the lack of growth at 30 and $37{ }^{\circ} \mathrm{C}$ do not allow this fungus to be classified within pathogens that invade the surfaces and deep tissues of mammals or plants. This research contributes to our understanding of cave ecosystem, in particular to characterize the underground mycobiota and their role in the occupied ecological niche. Therefore, in the near future, we are also going to perform further studies for in-depth characterization of P. glandicola from Driny Cave.

Acknowledgments We thank Dr. Ján Zuskin and Dr. Zuzana Višňovská from Slovak Caves Administration for help in the study. This project was co-financed by the Ministry of Science and Higher Education carried out by the University of Wrocław "Grant to Young Researchers". Grant number: 0420/1398/16.

Open Access This article is distributed under the terms of the Creative Commons Attribution 4.0 International License (http://creativecommons.org/licenses/by/4.0/), which permits unrestricted use, distribution, and reproduction in any medium, provided you give appropriate credit to the original author(s) and the source, provide a link to the Creative Commons license, and indicate if changes were made. 


\section{References}

Al-Fakih AA (2014) Overview on the fungal metabolites involved in mycopathy. OJMM 4:38-63. doi:10.4236/ojmm.2014.41006

Allemand L, Bahn PG (2005) Best way to protect rock art is to leave it alone. Nature 433(7028):800. doi:10.1038/433800c

Barton HA (2006) Introduction to cave microbiology: a review for the non-specialist. J Cave Karst Stud 68(2):43-54

Barton HA, Northup DE (2007) Geomicrobiology in cave environments: past, current and future perspectives. J Cave Karst Stud 69(1): $163-178$

Bastian F, Alabouvette C (2009) Lights and shadows on the conservation of a rock art cave: the case of Lascaux Cave. Int J Speleol 38:55-60. doi:10.5038/1827-806X.38.1.6

Bastian F, Jurado V, Nováková A, Alabouvette C, Saiz-Jimenez C (2010) The microbiology of Lascaux Cave. Microbiology 156:644-652. doi:10.1099/mic.0.036160-0

Bella P, Hlavac J, Gazik P (2001) Protection and management of show caves in Slovakia: 13th international congress of speleology, 4th Speleological congress of Latin América and Caribbean, 26th Brazilian congress of speleology Brasília, 15-22, July, 2001, pp 287-290

Berner M, Wanner G, Lubitz W (1997) A comparative study of the fungal flora present in medieval wall paintings in the chapel of the castle Herberstein and in the parish church of St. Georgen in Styria, Austria. Inter Biodeter Biodegr 40(1):53-61

Bezerra JD, Santos MG, Svedese VM, Lima DM, Fernandes MJ, Paiva LM, Souza-Motta CM (2012) Richness of endophytic fungi isolated from Opuntia ficus-indica Mill. (Cactaceae) and preliminary screening for enzyme production. World J Microbiol Biotechnol 28(5):1989-1995. doi:10.1007/s11274-011-1001-2

Borda DR, Năstase-Bucur RM, Spînu M, Uricariu R, Mulec J (2014) Aerosolized microbes from organic rich materials: case study of bat guano from caves in Romania. J Cave Karst Stud 76(2):114126. doi: $10.4311 / 2013 \mathrm{MB} 0116$

Bridge PD (1985) An evaluation of some physiological and biochemical methods as an aid to the characterization of species of Penicillium subsection Fasciculata. J Gen Microbiol 131:1887-1895

Briestenskỳ M, Stemberk J, Michal J, Bella P, Rowberry M (2011) The use of a karstic cave system in a study of active tectonics: fault movements recorded at Driny Cave, Male Karpaty Mts (Slovakia). J Cave Karst Stud 73(2):114-123. doi:10.4311/ jcks2010es0166

Burford EP, Kierans M, Gadd GM (2003) Geomycology: fungi in mineral substrata. Mycologist 17(3):98-107

Cwalina B (2008) Biodeterioration of concrete. Architect Civil Eng Environ 4:133-140

Dobinson KF, Lecomte N, Lazarovits G (1996) Production of an extracelular trypsin-like protease by the fungal plant pathogen Verticillium dahliae. Can J Microbiol 43:227-233

Doyle JJ, Doyle JL (1987) A rapid DNA isolation procedure for small quantities of fresh leaf tissue. Phytochem Bull 19:11-15

Frisvad JC, Samson RA (2004) Polyphasic taxonomy of Penicillium subgenus Penicillium. A guide to identification of food and airborne terverticillate Penicillia and their mycotoxins. Stud Mycol 49:1-174

Garg KL, Jain KK, Mishra AK (1995) Role of fungi in the deterioration of wall paintings. Sci Total Environ 167:255-271

Gorbushina AA, Heyrman J, Dornieden T, Gonzalez-Delvalle M, Krumbein WE, Laiz L, Petersen K, Saiz-Jimenez C, Swings J (2004) Bacterial and fungal diversity and biodeterioration problems in mural painting environments of St. Martins church (Greene-Kreiensen, Germany). Inter Biodeter Biodegr 53:1324. doi:10.1016/j.ibiod.2003.07.003

Griffin DW, Gray MA, Lyles MB, Northup DE (2014) The transport of nonindigenous microorganisms into caves by human visitation: a case study at Carlsbad Caverns National Park. Geomicrob J 31(3):175-185. doi:10.1080/01490451.2013.8152 94

Gupta R, Ramnani P (2006) Microbial keratinase and their prospective applications. Appl Microbiol Biotechnol 70(1):21-33

Ivanova V, Tomova I, Kamburov A, Tomova A, Vasileva-Tonkova E, Kambourova M (2013) High phylogenetic diversity of bacteria in the area of prehistoric paintings in Magura Cave, Bulgaria. J Cave Karst Stud 75(3):218-228. doi:10.4311/2012MB0279

Jurado V, Laiz L, Rodriguez-Nava V, Boiron P, Hermosin H, SanchezMoral S, Saiz-Jimenez C (2010) Pathogenic and opportunistic microorganisms in caves. Inter J Spele 39(1):15-24. doi:10.5038/1827-806X.39.1.2

Kubátová A, Dvořák L (2005) Entomopathogenic fungi associated with insect hibernating in underground shelters. Czech Mycol 57(3-4):221-237

Lehotská B, Bačkor P, Bobáková L, Fulín M, Lehotský R, Matis Š, Pjenčák P, Uhrin M, Višňovská Z (2011) Zhrnutie poznatkov o netopieroch v sprístupnených jaskyniach na Slovensku (summary of knowledge about bats in show caves in Slovakia). Aragonit 16(1):76-77 (in Slovak)

Marshall Hathaway JJ, Garcia MG, Moya Balasch M, Spilde MN, Stone FD, De Lurdes M, Dapkevicius NE, Amorim IR, Gabriel R, Borges PAV, Northup DE (2014) Comparison of bacterial diversity in Azorean and Hawai'ian lava cave microbial mats. Geomicrob J 31(3):205-220. doi:10.1080/01490451.2013.7774 91

Martínez MJ, Alconada TM, Guillén F, Vázquez C, Reyes F (1991) Pectic activities from Fusarium oxysporum f.sp. melonis. Purification and characterization of an exopolygalacturonase. FEMS Microbiol Lett $81: 145-150$

Martin-Sanchez PM, Sanchez-Cortes S, Lopez-Tobar E, Jurado V, Bastian F, Alabouvettec C, Saiz-Jimeneza C (2011) The nature of black stains in Lascaux Cave, France, as revealed by surfaceenhanced Raman spectroscopy. J Raman Spectrosc 43:464-467. doi:10.1002/jrs.3053

Martin-Sanchez PM, Nováková A, Bastian F, Alabouvette C, SaizJimenez C (2012a) Use of biocides for the control of fungal outbreaks in subterranean environments: the case of the Lascaux Cave in France. Environ Sci Technol 46(7):3762-3770. doi:10.1021/es2040625

Martin-Sanchez PM, Nováková A, Bastian F, Alabouvette C, SaizJimenez C (2012b) Two new species of the genus Ochroconis, $O$. lascauxensis and $O$. anomala isolated from black stains in Lascaux Cave, France. Fungal Biology 116:574-589

McKenzie RL, Bjorn LO, Bais A, Iayis M (2003) Changes in biologically active ultraviolet radiation reaching the Earth's Surface. Photochem Photobiol Sci 2:5-15

Morita RY (1975) Psychrophilic bacteria. Bacteriol Rev 39:144-167

Mulec J, Oarga-Mulec A, Tomazin R, Matos T (2015) Characterization and fluorescence of yellow biofilms in karst caves, southwest Slovenia. Int J Speleol 44:107-114. doi:10.5038/1827-806X.44.2.1

Northup DE, Melim LA, Spilde MN, Hathaway JJM, Garcia MG, Moya M, Stone FD, Boston PJ, Dapkevicius MLNE, Riquelme C (2011) Lava cave microbial communities within mats and secondary mineral deposits: implications for life detection on other planets. Astrobiology 11(7):601-618. doi:10.1089/ast.2010.0562

Nováková A (2005) Interesting and rare saprotrophic microfungi isolated from excrements and other substrata in the Domica and Ardovská Caves (Slovak Karst National Park, Slovakia). In: Tajovský K, Schlaghamerský J, Pižl V (eds) Contributions to soil zoology in central Europe I. ISB AS CR, České Budějovice, pp 103-106

Nováková A (2009) Microscopic fungi isolated from the Domica Cave system (Slovak Karst National Park, Slovakia). A review. Int J Speleol 38(1):71-82 
Nudziková L (2014) Vývoj návštevnosti sprístupnených jaskýň na Slovensku od roku 2009 (course of show caves attendance in Slovakia since 2009). Aragonit 19(1-2):35-38

Ogórek R (2016) Enzymatic activity of potential fungal plant pathogens and the effect of their culture filtrates on seed germination and seedling growth of garden cress (Lepidium sativum L.). Eur J Plant Pathol 145(2):469-481. doi:10.1007/s10658-016-0860-7

Ogórek R, Lejman A (2015) Badania speleomikologiczne w wybranych obiektach podziemnego kompleksu Riese (Góry Sowie, Dolny Sląsk, Polska)/(Speleomycological research in the selected objects of underground Riese complex (Sowie Mountains, Lower Silesia, Poland)). Postęp Mikrobiol 54(4):344-353 (in Polish)

Ogórek R, Kozak B, Lejman A, Kalinowska K, Dyląg M (2012) Analiza genetyczna szczepów Candida albicans za pomocą techniki RFLP-PCR (Molecular typing of Candida albicans isolates using RFLP-PCR). Mikol Lek 19(3):109-114 (in Polish)

Ogórek R, Lejman A, Matkowski K (2013) The fungi isolated from the Niedźwiedzia Cave in Kletno (Lower Silesia, Poland). Int J Speleol 42(2):161-166. doi:10.5038/1827-806X.42.2.9

Ogórek R, Pusz W, Lejman A, Uklańska-Pusz C (2014a) Microclimate effects on number and distribution of fungi in the underground comlex in the Owl mountains (Góry Sowie), Poland. J Cave Karst Stud 76(2):146-153. doi:10.4311/2013MB0123

Ogórek R, Pusz W, Matkowski K, Pląskowska E (2014b) Assessment of abundance and species composition of filamentous fungi in the underground Rzeczka complex in Sowie Mountains (Lower Silesia, Poland). Geomicrobiol J 31(10):900-906. doi:10.1080/0 1490451.2014.907380

Ogórek R, Lejman A, Matkowski K (2014c) Influence of the external environment on airborne fungi isolated from a cave. PJES 23(2):435-440

Ogórek R, Dyląg M, Kozak B, Višňovská Z, Tančinová D, Lejman A (2016a) Fungi isolated and quantified from bat guano and air in Harmanecka' and Driny Caves (Slovakia). J Cave Karst Stud 78(1):41-49. doi:10.4311/2015MB0108

Ogórek R, Višňovská Z, Tančinová D (2016b) Mycobiota of underground habitats: case study of Harmanecká Cave in Slovakia. Microb Ecol 71(1):87-99. doi:10.1007/s00248-015-0686-4

Ogórek R, Dyląg M, Višňovská Z, Tančinová D, Zalewski D (2016c) Speleomycology of air and rock surfaces in Driny Cave (Lesser Carpathians, Slovakia). J Cave Karst Stud 78(2). doi: $10.4311 / 2015 \mathrm{MB} 0128$

Panda T, Nair SR, Kumar P (2004) Regulation of synthesis of the pectolytic enzymes of Aspergillus niger. Enzyme Microbiol Tech 34:466-473

Pekkarinen AI, Mannonen L, Jones BL, Niku-Paavola ML (2000) Production of proteases by Fusarium species grown on barley grains and in media containing cereal proteins. J Cereal Sci 31:253-261

Pitt JI, Cruickshank RH (1990) Speciation and synonym in Penicillium subgenus Penicillium - towards a definitive taxonomy. In:
Samson RA, Pitt JI (eds) Modern concepts in Penicillium and Aspergillus classification. Plenum Press, New York, pp 103-119

Popović S, Simić GS, Stupar M, Unković N, Predojević D, Jovanović J, Grbić ML (2015) Cyanobacteria, algae and microfungi present in biofilm from Božana Cave (Serbia). Int J Speleol 44:141-149. doi:10.5038/1827-806X.44.2.4

Pusz W, Ogórek R, Uklańska-Pusz C, Zagożdżon P (2014) Speleomycological research in underground Osówka complex in Sowie Mountains (Lower Silesia, Poland). Int J Speleol 43(1):27-34. doi:10.5038/1827-806X.43.1.3

Pusz W, Ogórek R, Knapik R, Kozak B, Bujak H (2015) The occurrence of fungi in the recently discovered Jarkowicka cave in the Karkonosze Mts. (Poland). Geomicrobiol J 32(1):59-67. doi:10. 1080/01490451.2014.925010

Saiz-Jimenez C, Miller AZ, Martin-Sanchez PM, Hernandez-Marine M (2012) Uncovering the origin of the black stains in Lascaux Cave in France. Environ Microbio 14(12):3220-3231. doi: 10.1111/1462-2920.12008

Schabereiter-Gurtner C, Saiz-Jimenez C, Piñar G, Lubitz W, Rolleke S (2004) Phylogenetic diversity of bacteria associated with Paleolithic paintings and surrounding rock walls in two Spanish caves (Llonin and La Garma). FEMS Microbiol Ecol 47:1-13

Seifert KA, Samson RA (1986) The genus coremium and the synnematous Penicillia. In: Samson RA, Pitt JI (eds) Advances in Penicillium and Aspergillus systematics. Plenum Press, New York, pp 143-154

Sterflinger K (2000) Fungi as geologic agents. Geomicrobiol J 17(2):97-124

Sustr V, Elhottova D, Kristufek V, Lukesova A, Nováková A, Tajovsky K, Triska J (2005) Ecophysiology of the cave isopod Mesoniscus graniger (Frivaldszky 1865) (Crustacea: Isopoda). Eur J Soil Biol 41(3-4):69-75. doi:10.1016/j.ejsobi.2005.09.008

Tomee JFCH, Kauffman HF (2000) Putative virulence factors of Aspergillus fumigatus. Clin Exp Allerg 30:476-484

Vanderwolf KJ, Malloch D, McAlpine DF, Forbes GJ (2013) A world review of fungi, yeasts, and slime molds in caves. Int J Speleol 42(1):77-96. doi:10.5038/1827-806X.42.1.9

Visagie CM, Houbraken J, Frisvad JC, Hong S-B, Klaassen CHW, Perrone G, Seifert KA, Varga J, Yaguchi T, Samson RA (2014) Identification and nomenclature of the genus Penicillium. Stud Mycol 78:343-371. doi:10.1016/j.simyco.2014.09.001

Walochnik J, Mulec J (2009) Free-living amoebae in carbonate precipitating microhabitats of karst caves and a new vahlkampfiid amoeba, Allovahlkampfia spelaea gen. nov., sp. nov. Acta Protozoologica 48(1):25-33

White TJ, Bruns T, Lee S, Taylor JW (1990) Amplification and direct sequencing of fungal ribosomal RNA genes for phylogenetics. In: Innis MA, Gelfand DH, Sninsky JJ, White TJ (eds) PCR protocols: a guide to methods and applications. Academic Press, New York, pp 315-322

Wynn-Williams DW (1990) Ecological aspects of Antarctic microbiology. Adv Microbial Ecol 11:71-146 